\title{
REDEFINING THE IMAGE OF THE CONTEMPORARY CITY - CHANGES IN LINGUISTIC AND CULTURAL REALMS - PRELIMINARY REMARKS
}

\author{
MARTA KOSZKO
}

\begin{abstract}
Contemporary cosmopolitan European cities have been recently undergoing considerable social changes. Although most of them can be described as multicultural, the character of their public space should be redefined due to the intensified influx of immigrants mainly from the Middle East and North Africa and the socio-cultural background they bring along. This social and cultural process has a significant influence on the internal and external image and the identity of the city. These notions can be discussed in reference to Meffert's (1989) concept of the city's identity and the image of a city, hence in reference to the system of visual identification, communication system and the city culture. A particular attention should be drawn to the language in the public space (linguistic landscape LL), ritualized public space and the overall image of the city. These naturally have to be considered in the context of the socio-cultural transformation of the European cities. It should also be pointed out that Meffert's theory may need to be slightly redefined in order to reflect the present-day urban cultural and linguistic reality.
\end{abstract}

Key words: image, identity, linguistic landscape (LL), communication, ritualized communication, culture, immigration, immigrants, urban public space, city, multiculturalism

\section{Introduction}

In the recent years Europeans have been vigilantly observing the intensified process of the immigration flow to the European continent. Countries such as Germany, the UK, Austria, Italy, Spain, Greece or Sweden have to face new challenges when 
dealing with such a great number of people who arrive with different life experiences but also, more significantly, with their own cultural background, which includes traditions, beliefs, symbols and values. The phenomenon of immigration is not new in the history of Europe, however, the scale on which it is happening is unprecedented. For this reason, this problem requires a detailed research and most of all, an open discussion among people from different scientific fields, including linguistics, socio-linguistics, sociology or psychology.

Major European cities have been perceived as multicultural for decades. Such places as London, Paris or Berlin have attracted newcomers since ever, for they have given them haven and also economic opportunities. People who inhabited these urban spaces contributed to the development and creation of multicultural public spaces, though sometimes restricted to particular districts, suburban ghettos, which consequently have been one of the crucial elements constituting the overall image of a particular city.

The notion of 'the image of the city' is often discussed in reference to Meffert's (1989) concept of the city's identity and the image of a city, hence in reference to the system of visual identification, communication system and the city culture. In order to discuss the present socio-linguistic-cultural transformation of the European cities, a particular attention should be drawn to the language in the public space (linguistic landscape, LL), ritualized public space and the overall image of the city. Because of the ongoing changes it should also be pointed out that Meffert's approach may need to be slightly redefined in order to reflect the present-day urban cultural and linguistic reality.

\section{The illustration of the immigration process}

The majority of the recent immigrants to Europe have the status of refugees. This makes assimilation more difficult, as the travel to a new country was rather forced (e.g. military conflicts) than a voluntary one. The number of relocated people has grown rapidly and their countries of origin are very diverse. They include for example Syria, Albania, Iran, Ukraine etc. (see Chart 1 and Table 1).

Countries which have accepted the greatest number of refugees are Germany, Hungary, Sweden, Austria, Norway, France or Finland. Hence, the greatest transformations and modifications in the urban image can be expected in the cities of these countries. Germany, for example, received 442,000 first-time asylum applications in 2015, which has never happened before (Pew Research Center, August, 2016). 
Number of asylum seekers in Europe surges to record 1.3 million in 2015

Annual number of asylum applications received by EU-28 countries, Norway and Switzerland, 1985 to 2015



Chart 1. "Number of Refugees to Europe Surges to Record 1.3 Million in 2015" (Source: Pew Research Center, August, 2016)

Table 1. Countries of origin of the asylum seekers in Europe in 2015 (Source: Pew Research Center, August, 2016)

Syrians, Afghans, Iraqis were over half of all Europe's asylum seekers in 2015

Citizenship of first asylum applicants in Europe, 2015

\begin{tabular}{|l|r|r|}
\hline & Total & \% of all asylum applications \\
\hline Syria & 378,000 & 29 \\
Afghanistan & 193,000 & 15 \\
Iraq & 127,000 & 10 \\
Kosovo & 68,000 & 5 \\
Albania & 67,000 & 5 \\
Pakistan & 47,000 & 4 \\
Eritrea & 46,000 & 3 \\
Nigeria & 31,000 & 2 \\
Iran & 27,000 & 2 \\
Somalia & 21,000 & 2 \\
Ukraine & 21,000 & 2 \\
Serbia & 19,000 & 1 \\
Russia & 19,000 & 1 \\
Bangladesh & 18,000 & 1 \\
Gambia & 13,000 & 1 \\
Other & 230,000 & 17 \\
\hline TOTAL & $1,325,000$ & 100 \\
\hline
\end{tabular}

\section{Redefining the image of the contemporary city and its public space}

In order to understand how and why the image of the contemporary cities needs to be redefined, the ongoing changes in their socio-cultural public spaces should be discussed. However, the notions of multiculturalism and the image of the city should be given a closer look first. 


\subsection{A cosmopolitan city and multiculturalism}

Contemporary cities, especially the capital cities, are often cosmopolitan and multicultural. They are often described as: "urban areas whose cultures emphasize values including autonomy, freedom, egalitarianism, and mutual respect" (Mosterin 2005; in Sevincer, A.T, Kitayama, S. and M.E.W. Varnum 2015:1). These values seem to create an ideal space for future existence for a great number of relocated people. Furthermore, cosmopolitan cities are characterized by diversity and tolerance and can be the place of very special experiences (Muench 1991).

A great number of multicultural and cosmopolitan cities focus strongly on intercultural relations. It should be emphasized that the main idea of interculturalism focuses on "two rights: the right to difference and the right to the city. The right to difference means recognizing the legitimacy and specific needs of minority or subaltern cultures. The right to the city is the right to presence, to occupy public space, and to participate with others on equal basis in public affairs" (Sandercock, L., 2011:52). One of the challenges European cities have to face is the problem of integration. Multiculturalism requires "recognising diversity and indifferences. People from different cultural backgrounds may value the public space landscape quite differently to natives. Social integration allows cultural richness to open hearts and minds to different ways of seeing and experiencing public parks and landscapes. It can tell us something about the ways in which people adapt their traditions to different circumstances in a new country" (Binyi, L. and F.M. Mwanza, 2014: 12). Due to present societal changes some European cities change their character from predominantly homogenous to more diversified and multicultural, a situation already present in the major urban areas. The question which appears is whether with the present-day immigration the urban spaces will be able to fulfill the aforementioned criteria, which define multiculturalism.

\subsection{The image of the city}

The process of creating the image of the city is long and complex. It is inextricably related to the identity of the city. The image is created on the basis of what people (both the inhabitants of a particular city and the visitors) see and observe. It is a picture of the place they build in their minds, as a result of some promotional activities of the city's authorities (conscious, directional actions), by definition treated as positive, and further as a consequence of the influence of the elements placed in the public urban space (e.g. LL) on the recipients of this space. All the opinions and experiences evoked by a given place contribute to the overall image (see Rurański and Niemczyk, 2013; Stanowicka-Traczyk, 2008). 
The concept of the image can be also described as a static or dynamic phenomenon (Puppel, 2016). The first one refers to the picture people (here it can be said the city and those who create it) have about themselves as city inhabitants. It is crucial as there always exists some kind of confrontation with those others -newcomers/visitors. In the former sense, the image is constantly being crated by means of various actions (interactive-communicative) which further contribute to the creation of a particular picture in the recipients' minds (Puppel, 2016: 111). This dynamic character, as Stanowicka-Traczyk (2008) points out, means that the image of a city can change with the change of opinions and attitudes of the interactants. And these opinions and attitudes change with the changes in the public space. As Lynch (1960) points out, people experience the city and its elements are always perceived in some kind of context. The elements do not stand alone, they are all connected and interdependent. For every citizen, the city evokes specific memories and meanings. Hence, the observers may create a different image of the same city (Lynch, 1960). However, the image which appears in people's minds should be convincing, hence as Kowalewska and Puppel (2017: 95) indicate, it should be "complete, consistent and real".

\subsection{Meffert's (1989) concept of the city's identity and the image of the city}

The present discussion as well as many other discussions concerning the image and the identity of a city refers to the Meffert's (1989) concept of the city's identity and the image of a city. It is based on the assumption that the image of a city is created in relation to its identity. Hence, the identity is the main building block, which is formed from 3 main elements: the system of visual identification, communication system and the city culture. The first one consists of symbols, graphics connectedwith a city, a flag, colors, logo, pictograms etc. The second one encompasses com-

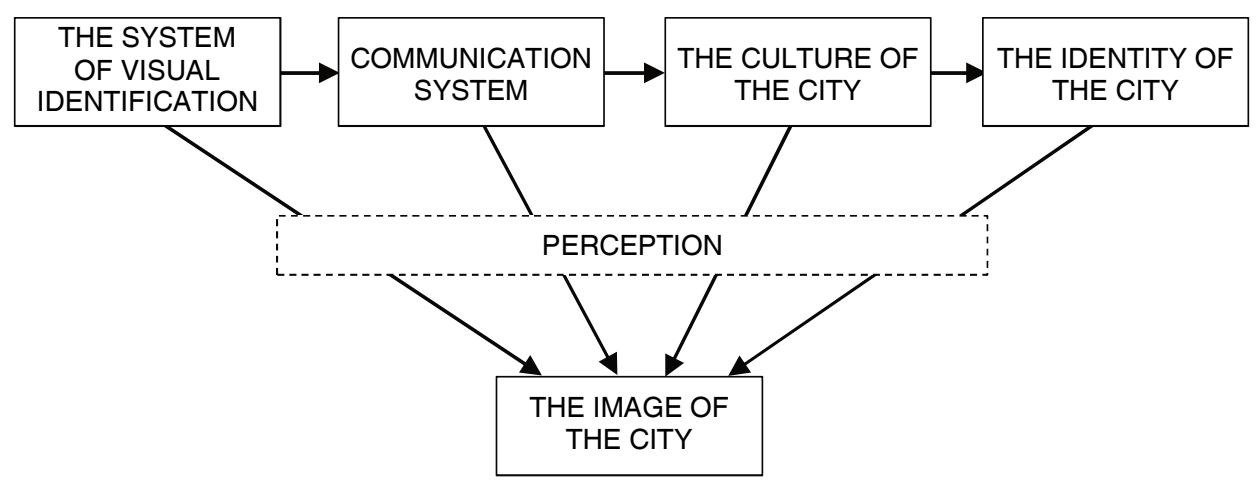

Picture 1. Meffert's idea of the image of the city - the main elements of the city's identity (my translation) (Meffert, H. 1989) 
munication with the inhabitants of the city and people with the visitors, everything that includes public relations. Finally, the third one refers to customs, traditions, norms, typical ways of behaviour characteristic for a particular community.

These three elements will be discussed and analyzed in reference to 3 following aspects:

1) language in the public space (linguistic landscape LL),

2) ritualized public space,

3) the overall image of the city.

They also have to be looked at in the context of the socio-cultural transformation of the European cities.

\subsubsection{The system of visual identification}

The system of visual identification includes among others symbols, coat of arms, graphic signs connected with a city, a flag, colors, logo, pictograms etc. The general definition of the concept is connected with visual signs characteristic for a particular city, hence for a particular majority dominant culture. For instance Berlin (the flag, see Picture 1), London (the flag, see Picture 2) or Malmö (the coat of arms, see Picture 3) - multicultural cities which face the challenge of intensified immigration, have their own specific visual identification - a flag or a coat of arms which refer to tradition, history of a particular city, thus culture.

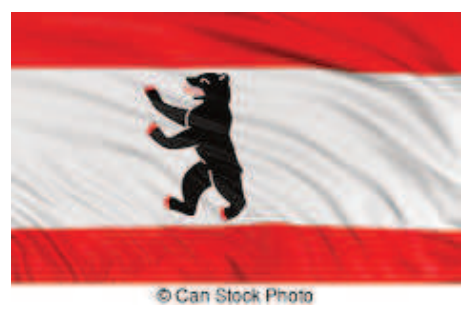

Picture 1. The flag of Berlin (source: http://www.flags-and-anthems.com/state/flag-berlin.html)

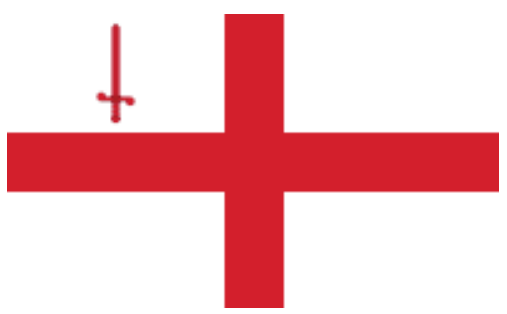

Picture 2. The flag of London (source: http://www.flags-and-anthems.com/city/flag-london.html) 




Picture 3. Malmö's coat of arms (source: http://www.ngw.nl/heraldrywiki/index.php?title=File:Malmo.jpg)

These cities are located in monolingual (one official language) countries, which are however multinational and multicultural. The image of a city in official visual realm however is related to German, British or Swedish cultures respectively. This though does not reflect the true picture of these metropolis, but only the dominant culture with the exclusion of the minorities. This also does not reflect the sociocultural reality. It can be therefore stated that this part of identity of a city is not largely affected by the ethnic changes in the society. If only this symbolic sphere was taken into consideration, the overall image of the mentioned cities would be that they are purely German, British or Swedish. The reality is however different.

\subsubsection{Communication system}

Communication system refers to communication between city authorities and the inhabitants of the city and with the visitors. It comprises all actions, which include public relations and ways of promoting the city. Although the definition may seem to refer to marketing and advertising notions, this discussion will focus on communication system as related to socio-ethno-linguistic aspects.

Each city wants to communicate with its inhabitants and also attract the attention of the visitors or newcomers who appear in the public space. If the present migration situation in Europe and the variety of nationals who settle in major European cities, speaking different languages than those of a host country, are taken into consideration, it is undeniably seen that cities are in a way forced to create and to allow the presence of multilingual messages in the public urban space. This aspect closely corresponds with the notion of linguistic landscape (LL). It can be briefly defined as language visible on signs both issued by official institutions (top-down) and those issued by private businesses (bottom-up) (see e.g. Landry and Bourhis, 1997, Ben- 
Rafael et. al., 2006). LL of major European cities has reached a rather stable form, it serves to prove that the languages of minorities, are accepted in the public space (e.g. London). LL clearly reflected not only the language policy of a particular city authorities (top-down signage), but also in a way the attitude of the inhabitants to the linguistic diversity in a city. Depending on the status of a particular minority the city issued signs in appropriate language, top-down signs, mainly in official language, as required by official policies in monolingual countries. Yet in the private realms characterized by bottom-up signs, communities have been allowed to communicate through signs in their own particular languages (see e.g. Grześkowiak, 2010; Görter, 2006; Ben-Rafael et.al., 2006). LL could be therefore treated as a well-established system of internal communication (within the city - between the inhabitants of the city from different cultural backgrounds) and external communication with the visitors. This idea and system however, may require reorganization due the growing number of people with entirely new linguistic backgrounds (they come from Syria, Afghanistan, Iraq, Kosovo). It has to be realized that LL may change or rather will have to change in order to acknowledge new European multinational communities, in which people from different linguistic and cultural backgrounds will coexist and will create new social space. They will try to show their presence in the form of LL, hence new languages may appear in the public space. The changing situation clearly corresponds with the features of multiculturalism, which is built upon acceptance of diversity and indifferences and different perception and experience of space (Binyi, L. and F.M. Mwanza, 2014).

\subsubsection{City culture}

This element, constituting the identity and the image of a city, comprises customs, traditions, norms, typical ways of behaviour characteristic for a particular community. It is expected that the culture of a city - next to the LL, will undergo the greatest changes. This will also bring along new challenges.

Each city presents customs, traditions, norms, typical ways of behaviour related to the dominant national culture in which it is located. Multinational cities, however, have to deal with and are often proud of their multicultural character where cultural norms, values and beliefs mix and create a specific culture peculiar to this particular place. For years people of different backgrounds have created ways for mutual understanding and acceptance despite differences and variety, taking a compromise to live next to others of entirely different cultural worldview. These are truly multicultural cities and urban spaces.

The culture of a city is related among others to rituals. As they are immersed in the public space, it can be said that public urban space is ritualized. The ritualization of space appears in a variety of areas, which constitute the definition of a ritual. It 
should be remembered that a ritual is not an entertainment, it is a part of a serious life. It is a kind of behaviour which shows social relations - hence it refers to symbols, which are connected with social relations, e.g. different kinds of gestures in human interactions or attire. Rituals are performed in agreement with customs. They are repeatable. It should be emphasized that a ritual is a formal activity, where symbolism is more important than technical or instrumental aspects and it is significantly related to social relations and order. A ritual has also a communicative and regulatory function, which is exposed in enhancing social bonds, i.e. social cohesion. It is visible in each community as there is always a need to maintain its opinions and beliefs. Finally, a ritual has always been related to orders and prohibitions and connected closely with religious and magical beliefs (Rothenbuhler, 2003). In reference to the aforementioned features, the following areas, which represent ritualized form of communication in a public space, can be distinguished e.g.:

appearance - clothes - religious manifestation - for example, the case of Mus$\lim$ women,

religious places - cemeteries, temples, mosques etc.

ways of behaviour - often connected to religion/language - specific gestures etc. religious events - e.g. Ramadan.

These four areas create ritualized public urban space, hence they create a specific identity and image. If for example appearance or ways of behaviour are taken into consideration, it should be emphasized that they contribute to the image, as the holistic picture of a person is based on its character, how a person communicates (including language used), how a person moves or what actions they are involved in (Kowalewska, 2018: 3), features which will often distinguish immigrants from the indigenous inhabitants. Religious places, for example cemeteries, as Puppel and Koszko (2017: 513) point out, create "specific space where language, culture, religion and secular elements are combined" (my translation). They are hence manifestation of identity of a present group. The aforementioned forms of ritualized communication often serve as the main way to manifest ethnic belonging and maintain original culture by the immigrants, especially by those who have just arrived. Taking into consideration the masses of people who begin a new life on the European continent, it should be realized that for them this is often a completely culturally foreign land and the rituals (customs, traditions etc.) of their culture allow them to maintain their culture. This situation has an incredibly visible influence on the image of the cities. In many cases minorities inhabit chosen districts, where they create their own homeland, with their shops, food, language, signage, institutions etc. However, with the new flow of people, and much greater number of them, people of different cultural background will go beyond these districts, often treated as ghettos. Such a phenomenon can contribute to the overall image of a city and London is a good example, where ritualized public space is not restricted to particular districts (though intensified there), contrary to Paris, which tends to keep ritualization away from its centre. 


\subsection{Conclusions - the new identity and image of the European cities}

Present changing social situation in the European cities modifies the image of the cities. Therefore, Meffert's diagram requires changes, which is suggested in Diagram 2 below.

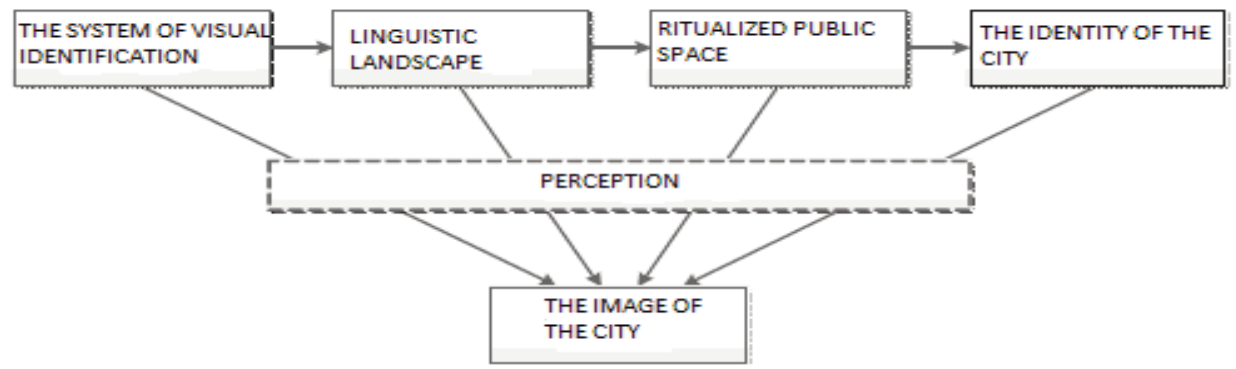

Diagram 2. Meffert's diagram changed

What has been predictable so far, i.e. the traditional approach to identity and image of a city, is now undergoing visible changes. The inhabitants of the cities may be facing:

a growing number of multilingual signage in the public space (LL)

more visible different styles of clothes as a manifestation of ethic belonging, an increasing number of worship places, e.g. mosques or temples,

different ceremonies and events related to a given culture, often of religious character (e.g. Ramadan).

All these elements will create a new modified image of a city.

\section{References}

Ben-Rafael, E. Shohamy, E., Amara, M.H. and N. Trumper-Hecht. 2006. "Linguistic landscape as symbolic construction of the public space: the case of Israel". International Journal of Multilingualism 3.1. 7-30.

Binyi, L. and F.M. Mwanza. 2014. "Social integration in public spaces and landscapes: perceptions and experiences towards multicultural Shanghai". Chinese Studies 3.1.12-18. Published online February 2014 in SciRes.

Connor, P. 2016. "Asylum report final". Pew Research Center Europe. Washington, D.C.: August. http://assets.pewresearch.org/wp-content/uploads/sites/2/2016/08/14100940/Pew-Research-CenterEurope-Asylum-Report-FINAL-August-2-2016.pdf 
Grześkowiak, M. 2010. Trans-city or Inter-city? The co-existence of majority and minority languages in the urban space: a comparative case study of London and Warsaw linguistic landscapes. Poznań: Katedra Ekokomunikacji UAM.

Görter, D. (ed.) 2006. Linguistic landscape. A new approach to multilingualism. Clevedon: Multilingual Matters.

Kowalewska, K. 2018. "Wizerunek starości i osób starszych wśród uczniów na poziomie szkoły podstawowej”. Studium Vilnense A 15. 146-151.

Kowalewska, K. and J. Puppel. 2017. "Wizerunek i wskaźnikowość układów ciała w reklamie prasowej - uwagi i badanie wstępne”. Scripta Neophilologica Posnaniensia. XVII. 495-502.

Landry, R. and R.Y. Bourhis. 1997. "Linguistic landscape and ethnolinguistic vitality: an empirical study." Journal of Language and Social Psychology 16.1. 23-49.

Meffert, H. 1989. “Städtemarketing - Pflicht oder Kür?”. Planung und Analyse 8. 277.

Mosterin, J. 2005. "A world without national states". Acta Inst.Philos.Aesthet. 23. 55-77.

Sevincer, A.T., Kitayama, S. and M.E.W. Varnum. 2015. "Cosmopolitan cities: the frontier in the twenty-first century?”. Front. Psychol. 6:1459. doi: 10.3389/f.psyg.2015.01459.

Muench, W. 1991. "Die Stadt und die dynamik der kulturellen erneuerung [The city and the dynamics of cultural reformation]," In: Gephard, W. and H.P. Schreiner (eds.). Stadt und Kultur [City and Culture]. Duesseldorf: Leske und Buderich. 59-82.

Puppel, S. 2016. "Kuźnia Hefajstosa czyli krótki zarys teorii wizerunku w komunikacji człowieka". Scripta Neophilologica Posnaniensia XVI. 109-124.

Puppel, J. and M. Koszko. 2017. "Wizerunek cmentarza - w wymiarze języka, kultury, dziedzictwa uwagi wstępne na przykładzie cmentarza Mennonitów w Stogach Malborskich". Scripta Neophilologica Posnaniensia XVII. 513-522.

Rothenbuhler, E.W. 2003. Ritual communication: from everyday conversation to mediated ceremony. Thousand Oaks [etc.]: Sage Publications.

Rurański, M. and J. Niemczyk. 2013. "Współczesne instrumenty kształtowania wizerunku miasta na przykładzie Wrocławia”. Studia Miejskie 11. 67-78.

Stanowicka-Traczyk, A. 2008. Ksztaltowanie wizerunku miasta na przykladzie miast polskich. Bydgoszcz/Olsztyn: Oficyna Wydawnicza Branta.

Sandercock, L. 2011. "Towards a cosmopolitan urbanism: from theory to practice”. Dialogues in Urban and Regional Planning 4. 38-57. 